Estudos da Língua(gem)

Estudos em Sintaxe Gerativa

\title{
The relationship between subject position, focus and agreement in passive constructions in Brazilian Portuguese ${ }^{1}$
}

\author{
A relação entre a posição de sujeito, foco e \\ concordância nas construções passivas do Português Brasileiro
}

\section{Leonor SIMIONI*}

Universidade Estadual de São Paulo (Brasil)

\begin{abstract}
This paper discusses the agreement patterns of passive structures in Brazilian Portuguese (BP). More specifically, we claim that the fact that postverbal DPs in such structures don't necessarily trigger agreement on the verb and the participial head, whereas moved DPs always do, represents a problem for the Agree model proposed by Chomsky (1998 and subsequent work). We adopt Hornstein's (2009) model, which eliminates Agree from the grammar, and propose that these postverbal DPs are actually focused in BP. The defective agreement patterns are suggested to be a consequence of the focused status of the DPs.
\end{abstract}

${ }^{1}$ Pesquisa financiada pela FAPESP, processos 2006/00965-2 e 2008/00244-9.

*Sobre a autora ver página 187.

\begin{tabular}{l|l|l|l|l}
\hline Estudos da Língua(gem) & Vitória da Conquista & v. 8, n. 2 & p. 173-187 & dezembro de 2010 \\
\hline
\end{tabular} 


\section{KEYWORDS}

Agreement. Focus. Passive Constructions. Postverbal DPs.

RESUMO

Este artigo discute os padrões de concordância nas construcões passivas no Português Brasileiro (PB). Mais especificamente, argumentamos que o fato de os DPs pós-verbais não necessariamente dispararem concordância com o verbo e com o núcleo de participio nessas estruturas, enquanto os DPs movidos sempre o fazem, representa um problema para o modelo de Agree proposto por Chomsky (1998 e trabalhos seguintes). Adotamos o modelo de Hornstein (2009), que elimina a operação Agree da gramática e propomos que esses DPs pós-verbais são, na verdade, focalizados no PB. Sugerimos que os padrões de concordância defectiva são consequência da focalização desses elementos.

PALAVRAS-CHAVE

Concordância. Foco. Construções Passivas. DPs pós-verbais.

\section{Introduction}

On standard Brazilian Portuguese (henceforth BP) passive sentences, the subject DP, the participle head and the verb all display agreement morphology, whether the argument is moved or in situ:

(1) a. As provas foram deixadas na sala. theFEMPL testsFEMPL were3PL leftFEMPL in-the room 'The tests were left in the room.'

b. Foram compradas umas tortas deliciosas pra festa. were3PL boughtFEMPL someFEMPL piesFEMPL deliciousFEMPL forthe party.

'Some delicious pies were bought for the party.'

However, we also find passive constructions that display an incongruence of gender and number agreement, such as $(2)^{2}$ :

\footnotetext{
${ }^{2}$ At least in some registers of BP. According to Naro \& Scherre (2007, p. 12), the variable agreement phenomena in BP are territorially widespread and can be found in the whole country. The relevant factor, according to these authors, is social, mainly the years of study and the opposition urban vs. rural speakers.
} 
(2) a. Foi bebido trinta garrafas de cerveja na festa ontem. was3sG drankMASCSG thirty bottlesFEMPL of beer at-the party yesterday.

'Thirty bottles of beer were drank at the party yesterday.'

b. Antes do casamento, foi espalhado pétalas de rosa pelo chão da igreja. before the wedding, was3sg spreadMASCSG petalsFEMPL of rose on-the floor of-the church.

'Before the wedding, rose petals were spread on the church floor.'

c. Foi deixado as provas na sala. was3sG leftMASCSG theFEMPL testSFEMPL in-the room 'The tests were left in the room.'

Crucially, such incongruence is only possible when the DP argument is in situ, as we can observe in the examples in (3):

(3) a. *Trinta garrafas de cerveja foi bebido na festa ontem. thirty bottlesFEMPL of beer was3sG drankMASCSG at-the party yesterday.

'Thirty bottles of beer were drank at the party yesterday.'

b. *Antes do casamento, pétalas de rosa foi espalhado pelo chão da igreja. before the wedding, petalsFEMPL of rose was3sG spreadMASCSG around-the floor of-the church.

'Before the wedding, rose petals were spread around the church floor'

c. *As provas foi deixado na sala.

theFEMPL testsFEMPL was3sg leftMASCSG in-the room

'The tests were left in the room.'

The data in (1) - (3) pose three questions: (i) how to account for the optional agreement with in situ arguments; (ii) why the moved DP always triggers agreement; and (iii) what is the status of the postverbal $\mathrm{DP}$ and how is it licensed? The present work.

\section{Movement and agreement}

The data presented in the introduction are interesting from a theoretical point of view, given that recent advances of the Minimalist Program (CHOMsky, 1998 and subsequent work) propose the elimination 
of the Spec-Head configuration as a "special one" and propose Agree as the operation of the computational system of human language responsible for agreement. This operation consists on the establishment of a longdistance relationship between a probe $<$ and a goal $\beta$ in the course of the derivation whenever the following conditions are met: (i) the probe $<$ must have uninterpretable $\phi$-features and must c-command the target $\beta$; (ii) the features of the probe $<$ and the goal $\beta$ must match; (iii) there should be no alternative goal $\gamma$ such that $<\mathrm{c}$-commands $\gamma$ and $\gamma$ c-commands $\beta$; and (iv) the goal $\beta$ must be active to the system, that is, it must have an uninterpretable feature to be checked. Let's see how the derivation of a standard passive such as (1a) would be according to this system ${ }^{3}$ :

(4) As provas foram deixadas na sala

a) $\left[_{\mathrm{PpleP}}-\mathrm{en}_{[\mathrm{G}: \mathrm{:}] /[\mathrm{N}::] /[\text { Case:?] }}\left[_{\mathrm{VP}}\right.\right.$ leave $\left.[\text { the tests }]_{\text {[P:3]/[G:FEM]/NN:PL]/[Case:?] }}\right]$

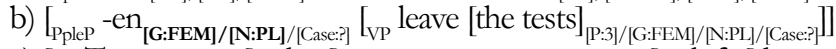

c) $\left[_{\mathrm{TP}} \mathrm{T}_{[\mathrm{P}: \mathrm{P}] / \mathrm{N}: \mathrm{:}] / \mathrm{EPP}}\left[_{\mathrm{VP}}\right.\right.$ be $\left[_{\mathrm{PpleP}}-\mathrm{en}\right.$ [G:FEM]/[N:PL]/[Case:?] ${ }_{\mathrm{VP}}$ left [the tests] [P:3]/[G:FEMM]/NN:PL]/[Case::]]]]

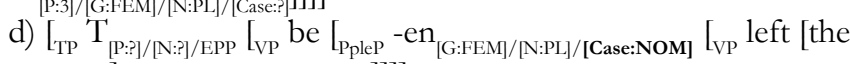
tests] $]_{[\mathrm{P}: 3] /[\mathrm{G}: \mathrm{FEM} / / \mathrm{N}: \mathrm{PL} /[\mathrm{Case:}:]]]]}$

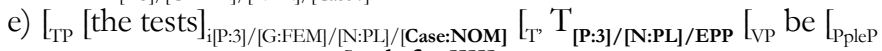
$-\mathrm{en}_{[\mathrm{G}: \mathrm{FEM} /[\mathrm{N}: \mathrm{PL}] /[\text { Case:NOM] }}\left[\mathrm{VP}\right.$ left $\left.\left.\left.\left.\left.t_{\mathrm{i}}\right]\right]\right]\right]\right]$

On step (b), the participial head, after entering the derivation, probes the DP in order to value its number and gender features. Since neither the participial head nor the DP have an unvalued person feature, both remain with their Case features unvalued ${ }^{4}$. On step (d), T probes the participial head in order to value its person and number features; however, since the participial head is $\phi$ defective, none of T's features gets valued. But since Thas an uninterpretable person feature, the Case feature of the participial head gets valued as Nominative. Finally, on step (e) T probes the DP, valuing its own features and also the Case feature of the DP as Nominative. The DP then moves due to the EPP-feature of T.

In order to generate (1b), the derivation would be identical to the

\footnotetext{
${ }^{3}$ English words will be used in the derivations for convenience.

${ }^{4}$ It has been assumed that only a full $\varphi$-set (more specifically, a $\varphi$-set which contains an unvalued person feature) can value the Case feature of a DP.
} 
one in (4), the only difference being the absence of an EPP feature on $\mathrm{T}$, which leaves the DP in situ. As for the licensing of the Case feature of the DP, there are (at least) two options: either it would be valued Nominative by $T$ via the long-distance relationship, or it could get valued as partitive, following Belletti (1988) $)^{5}$.

When we try to account for the contrast between (2) and (3), however, things are far from obvious. Recall that one of the conditions for the application of Agree is that the probe must c-command the target; therefore, data such as (2) are unexpected, because all the conditions for the operation Agree to apply are met. The same goes for the data in (3) if the Spec-Head relationship really isn't special in the grammar and, consequently, relevant for the establishment of agreement. Following the logic of this model, if an unmoved DP doesn't necessarily trigger agreement in a given register of BP, so shouldn't the moved DP. But what, then, could be the answer to this puzzle?

Interestingly, the same kinds of agreement patterns are called upon by Hornstein (2009) to give empirical support to his claim that a system with both Move and Agree operations is redundant. The author proposes the elimination of the latter, because what we actually see across languages is the subject of the sentence being pronounced in a higher position (Spec,TP); for Hornstein, this is easily accounted for if Spec-Head is the configuration responsible for agreement, therefore forcing movement of the DP to this position, whereas in the Agree model the movement to Spec,TP must be generated in a more stipulative way ${ }^{6}$.

Incorporating the Copy Theory of Movement (CHOMsKY, 1995), Hornstein then proposes that agreement be a consequence of the movement of a copy of the DP to Spec,TP in order to check its Case feature and the $\phi$-features of $\mathrm{T}$; later in the derivation, the lower copy gets deleted and only the upper copy is pronounced. One of the empirical arguments used by the author to support this idea is exactly

\footnotetext{
${ }^{5}$ The absence of an EPP-feature on $\mathrm{T}$ and the valuation of the Case of the DP as partitive are suggested by Nunes (2007).

${ }^{6}$ In the Agree model, this movement is said to be triggered by the existence of an EPP-feature on the head $\mathrm{T}$, which would signal to the system that the head that bears it must have some material filling its Spec position. Much current work is devoted to deriving the EPP from other properties of the grammar.
} 
the fact that we find, crosslinguistically, various cases of unmoved DPs not triggering agreement, whereas cases of moved DPs not triggering agreement are not found. One of the examples given by Hornstein is the existential construction in English:

(5) a. There seem/seems to be men in the garden

b. There are/is a dog and a cat on the roof

c. ${ }^{*}$ Men seems to be in the garden

d. *A dog and a cat is on the roof (ex. (12), ch. 6. HORNSTEIN)

As we can see by the examples above, the verb doesn't need to agree with the associate of the expletive $(a, b)$, but it must agree with the DP when it's in its Spec (c,d), in precisely the same way attested in BP passive structures. So, his model accounts for the reason why moved DPs always trigger agreement, thus answering the second question posed in the introduction. But as it answers that question, this model also poses a new one: if a DP moves to Spec,TP in order to be licensed, why is it the case that it doesn't always move? Why are there occasions in which the DP is allowed to remain downstairs, and how is it licensed in these cases?

Once assuming the Copy Theory of Movement, Hornstein proposes that in those cases, the derivation of both structures is the same: one copy of the DP moves to Spec,TP, gets is Case checked and checks the $\phi$-features of T. The difference lies on the choice of the copy to be pronounced: when the derivation comes to the point of linearization of the structure, the lower copy is selected for pronunciation, and the upper copy is deleted. But why would the upper copy be deleted if it is the most specified one? Nunes (2004) claims that lower copy pronunciation is always tied up to PF requirements. This being so, the hypothesis to be entertained in the present work is that in $\mathrm{BP}$, as in other languages ${ }^{7}$, the DP argument of the passive structure is pronounced in situ when it is the focus of the sentence, or when it is part of it. In the remainder of this paper we will investigate this possibility

${ }^{7}$ Cf. Stjepanovic (2003) for Serbo-Croatian and Bailyn (1995) for Russian. Bošković (2007, p. 629) entertains this possibility for other languages when discussing his version of Agree. 
more closely. We will also try to relate the focused status of these DPs to the reason why verbs optionally agree with them.

\section{Focus and the postverbal position}

One of the languages in which a postverbal DP may be focused is Italian. According to Cardinaletti (2001), a postverbal subject may occupy two different positions in that language: it can either remain in situ, receiving a contrastive focus interpretation (examples (6) and (7)), or it can be right-dislocated and not have a focus interpretation (the focused element in these cases tends to be the object) ${ }^{8}$. Importantly, both positions behave the same regarding agreement:

(6) A: Ho sentito che Maria non há invitato nessuno. have1sG heard that Mary not has3sg invited nobody 'I've heard that Mary didn't invite anyone.'

B: No, non ha invitato GIANNI, nessuno. no not has3sG invited John nobody 'No, JOHN didn’t invite anyone.'

(7) pro ha comprato il giornale GIANNI (non Maria). has3sg bought the newspaper John (not Mary) 'JOHN has bought the newspaper.'

(8) A: Cosa ha portato, Gianni? what has3sg brought John 'What did John bring?'

B: Ha portato IL DOLCE, Gianni. has3sg brought the candy John 'John has brought THE CANDY.'

There is one Italian dialect, however, that distinguishes a focused, in situ DP from a right-dislocated one via agreement. In Anconetano the verb does not agree in number with a "true" postverbal subject:

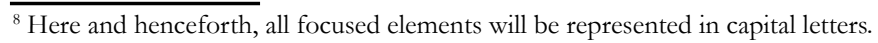


(9) a. $\mathrm{Ha}$ fatto I BAMBINI il disegno (non la maestra). $\mathrm{V}_{\mathbf{S}} \mathrm{O}^{9}$ has3sG made thePL kidspl thesG drawingSG 'THE KIDS have made the drawing.' (not the teacher)

b. $\mathrm{Ha}$ fatto il disegno QUEI BAMBINI LI. VOS $\underline{1}^{10}$ has3SG made thesG drawingsG thosepL kidspL there 'THOSE KIDS have made the drawing.'

Monoargumental verbs behave in the same fashion, indicating that their argument DP is also in situ. When the DP is right-dislocated, on the other hand, agreement is obligatory, showing that they are, in fact, in two different positions:

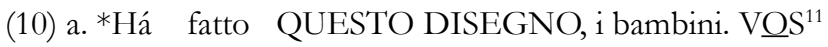

has3sG made thissG drawingsG thePL kidsPL.

'The kids have made THIS DRAWING.'

b. Hanno fatto QUESTO DISEGNO, i bambini. Vㅡㅗ

have3PL made thissG drawingsG thePL kidsPL

'The kids have made THIS DRAWING.'

The data from Anconetano are of interest here because they show a clear difference between focused $v$ s. non-focused postverbal DPs, and this difference is coded in terms of agreement. So we can entertain the hypothesis that in BP passives, the difference between a postverbal DP that triggers agreement $v s$. one that doesn't is that only the latter is focused. We will come back to this point; but first let's examine a somewhat different approach to postverbal focused elements.

Belletti (2001) agrees with Cardinaletti (2001) that postverbal in situ DPs in Italian are focused; nevertheless, she claims that they are not necessarily always interpreted as a contrastive focus. She also proposes that focalized postverbal subjects of transitive and inergative verbs are not really in situ, but actually move to the specifier of a lower focus position in the structure, located between TP and vP. The simplified bracketed structure below illustrates the proposal ${ }^{12}$ :

\footnotetext{
${ }^{9}$ Example (42a) in the original.

${ }^{10}$ Example (38b) in the original.

${ }^{11}$ Examples (42b,c) in the original.

${ }^{12}$ According to Belletti (2001), the licensing of these DPs is achieved via the Spec-Head relationship with the Focus head and the checking of a focus feature as a consequence.
} 
(11)

$$
\left[_ { \mathrm { TP } } \cdots \left[_ { \text { FocusP } } \text { Subject } _ { \mathrm { i } } \text { Focus } \ldots \left[_{\mathrm{VP}} \cdots\left[_{\mathrm{VP}} \text { Subject }_{\mathrm{i}} \ldots\right]\right.\right.\right.
$$

With postverbal arguments of unaccusative verbs, on the other hand, things are a bit different: the in situ DP is really in situ, and is licensed via an inherent partitive Case assignment, following the own author's previous work (BELLETTI, 1988). For these cases, the author, also following her previous work, claims that only indefinite DPs may remain in situ and receive a partitive Case:

(12) a. $\grave{E}$ arrivato uno studente al ufficio. ${ }^{13}$ be 3 sG arrived oneINDEF student at-the office 'A student has arrived at the office.'

b. 亡̀ entrato um ladro dalla finestra. be3sG entered oneINDEF thief from-the window 'A thief has entered by the window.'

This restriction regarding definite postverbal arguments is known as the definiteness effect. But, as we saw in (2c), repeated here for convenience, apparently a definite DP may figure as postverbal in BP passive structures:

(13) Foi deixado as provas na sala. was3sg leftMASCSG theFEMPL testSFEMPL in-the room 'The tests were left in the room.'

In fact, Sibaldo (2007) shows that definite DPs may clearly occupy the postverbal position of unaccusatives ${ }^{14}$ in out of the blue contexts without marginality:

(14) a. De repente, entrou o homem no banco. ${ }^{15}$

'Suddenly, the man entered the bank.'

b. Aos poucos, chegaram os meninos na sala de aula.

'Little by little, the boys arrived in the classroom.'

\footnotetext{
${ }^{13}$ Examples (40) in the original.

${ }^{14} \mathrm{BP}$ has a strong restriction to postverbal subjects, and unaccusatives are the only kind of verb that allows postverbal arguments in BP.

${ }^{15}$ Examples (12) and (15) in the original.
} 
Since the passive voice has the same properties of unaccusatives ${ }^{16}$, we will assume that Sibaldo's conclusion is valid for passive constructions as well. In the next section, we will turn back to BP data in order to confirm the validity of the hypotheses casted out along this paper.

\title{
4 Relating focus and agreement in BP
}

One of the hypotheses to be confirmed is the possibility of interpreting a postverbal DP as focused. Mioto (2003) affirms that the "subject" of monoargumental verbs tends to be focused in postverbal position in BP. He assumes with Belletti (2001) that these DPs occupy a lower focus position in the structure. Mioto (2003) also shows that this lower focus may be interpreted as any kind of focus: information, contrastive, etc.

Going back to BP passives, if we apply Zubizarreta's questionanswer pairs to determine the focus structure of a sentence (ZUBIZARRETA, 1998), it becomes clear not only that the postverbal DP may be interpreted as an information focus, but also that the preverbal DP cannot. In (15), we have a context question in A, which gives us the presupposition, and two possible answers (B and $\left.\mathrm{B}^{\prime}\right)$, with the DP in situ vs. moved:

\author{
(15) A: O que (que) foi feito pro casamento do Paulo? \\ the what (what) was made for-the wedding of-the Paul \\ 'What was made for Paulo's wedding?' \\ B: Foi feito UM BOLO ENORME. \\ was made one cake enormous \\ 'An enormous cake was made.' \\ B': \#UM BOLO ENORME foi feito. ${ }^{17}$ \\ one cake enormous was made \\ 'An enormous cake was made.'
}

\footnotetext{
${ }^{16}$ Like unaccusatives, the participial form of the verb neither attributes a theta role to an external argument, nor a Case to the internal argument. Interestingly, despite the restriction to postverbal subjects in $\mathrm{BP}$ mentioned in footnote 12, passives may also display postverbal arguments in the language.

${ }^{17}$ The symbol "\#" will be used to indicate an inadequate use of the sentence.
} 
According to Mioto (2003), the sentence B' is not an adequate answer to the question because (i) if pronounced with a neutral intonation, the moved DP is interpreted as old information, which is incompatible with a focus reading; (ii) if pronounced with a marked intonation, the DP will be interpreted as being in the higher FocusP located above $\mathrm{CP}$, and this position, different from the lower FocusP, is only associated with a contrastive focus reading. This being so, we must conclude that the postverbal DP in passive structures in BP can be focused; actually, since B' is not an appropriate answer to the context question, we have to assume that, if one wants to focus the DP argument of a passive sentence, then one must leave such DP in a postverbal position.

Moving on to the agreeing $v s$. non-agreeing pattern with postverbal DPs, Zubizarreta's test is very revealing:

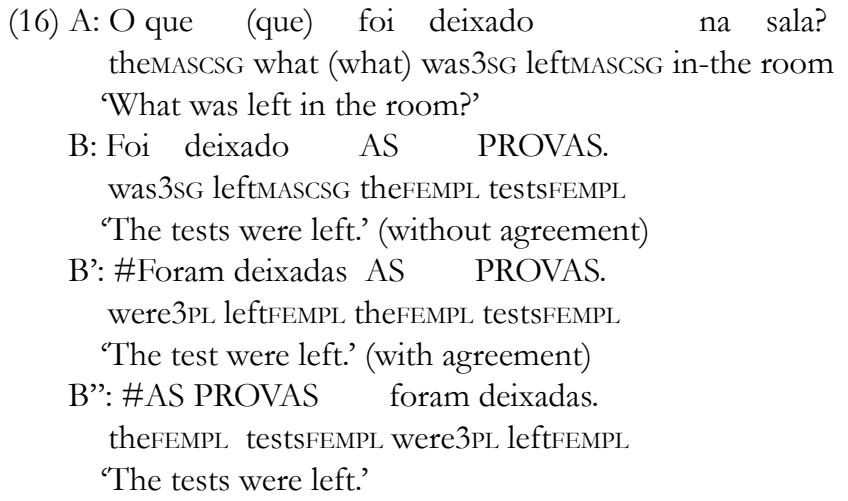

As we can see, the sentence B, with the postverbal DP and without agreement between the verb, the participial head and the postverbal DP is the only one which answers appropriately the context question $\mathrm{A}$. The sentence B', which displays agreement, is not an adequate answer. The answer B" was given just to reinforce the point made in example (15). This could be due to some sort of parallelism effect: since the context question is bare, the best answer is the bare one. In order to confirm this, let's see what happens when we reformulate the context question: 
(17) A: Que coisas (que) foram deixadas na sala? what thingsFempl (that) were3PL leftFEMPL in-the room 'What things were left in the room?'

B. Foi deixado AS PROVAS. was3sg leftMASCSG theFEMPL testSFEMPL 'The tests were left.'

B': Foram deixadas AS PROVAS. were3PL leftFEMPL theFEMPL testSFEMPL 'The tests were left.'

B": \#AS PROVAS foram deixadas. theFEMPL testsFEMPL were3PL leftFEMPL 'The tests were left.'

In fact, we can easily observe that when the context question isn't bare, B' becomes a good answer. Interestingly, though, sentence B, without agreement, is still a perfectly acceptable answer. So sentences of the "B" kind are good answers to both bare and inflected context questions, whereas "B"' kinds of questions are only good with the inflected version of the context question. But where does this conclusion leave us?

Let's take a moment to reflect upon the context question. According to Zubizarreta (1998), the focus is the non-presupposed part of the sentence, that is to say, the new information. The context question sets the background assumptions, i.e., the old information. Bearing that in mind, we can assume that the most adequate context question is a bare one, because the focused element is yet unknown - recall that we're talking about information focus. If that assumption were indeed correct, then the passive with a "true" focused DP would be precisely the one with no agreement ${ }^{18}$. As for the agreeing form of the passive structure with a postverbal DP, it is perfectly acceptable with a wide focus reading, or in out of the blue contexts ${ }^{19}$.

\footnotetext{
${ }^{18}$ In those BP registers in which the non-agreeing version of the passive is possible. Recall that in BP there are registers in which the non-agreeing passive does not exist. In such cases, it seems quite clear that focusing the DP in a passive sentence would only require the postverbal DP. The distinction of focused $v$ s. unfocused DPs based on agreement patterns is a "refinement" that is possible only in some BP registers, like the difference between Italian and the Anconetano dialect mentioned in the previous section.

${ }^{19}$ Reinhart (2006) affirms that passive voice constructions have only two focusing possibilities: either focusing the whole sentence (wide focus) or focusing only the subject (narrow focus).
} 
And what about the licensing of these DPs? If we assume with Mioto (2003) that any focus reading on a postverbal DP requires movement of this category to the specifier of a low Focus Phrase position, then in the sentences of the B type the DP is in Spec,FocusP (18), while in B' they are really in situ (19):

(18) $\left[_{\mathrm{TP}} \mathrm{T}\left[_{\mathrm{VP}}\right.\right.$ ser $\left[_{\mathrm{PpioP}}\right.$ Ppio $\left[_{\mathrm{Focus}}\right.$ uns documentos Focus $\left[_{\mathrm{VP}}\right.$ achar $\left[_{\mathrm{DP}}\right.$ uns doeumentos]]]]]]

$$
\left.\left[_{\mathrm{TP}} \mathrm{T}\left[_{\mathrm{VP}} \operatorname{ser}\left[_{\mathrm{Pp} \text { piop }} \text { Ppio [VP } \text { achar }\left[_{\mathrm{DP}} \text { uns documentos }\right]\right]\right]\right]\right]
$$

In (18), the DP moves to Spec,FocusP. Following Belletti (2001), we could assume that the focus feature checking suffices to license it; or it could be assigned a default Nominative value ${ }^{20}$. And in (19), since there is no narrow focus, we can assume that the focus head is not projected in the structure. This being so, the DPs would move to Spec,TP to get their Case feature checked. If Nunes (2004) is correct, the fact that the lower copy of the DP gets pronounced indicates that something in the PF side is forcing it. We don't have much to say on this matter yet, but our preliminary hypothesis is that there is a finer distinction between the out of the blue and the wide focus contexts that could be underlying this choice.

\section{Final remarks}

We started this paper with three questions to be answered. The first question was how to account for the optional agreement with in situ arguments, and the answer we attempted to provide is that the nonagreeing version of the passive is actually the structure for DP focusing. The second question was why does the moved DP always triggers agreement. Following Hornstein (2009), our answer was that the SpecHead relation is in fact the relevant configuration for agreement - which implies giving up the Agree model as it is. And finally, the third question

\footnotetext{
${ }^{20}$ Exactly how the default Nominative assignment should work is one of the issues we intend to address in future work.
} 
concerned the status of these postverbal DPs and their licensing. The first part of the question was already answered in the first one: these DPs are focused and occupy the specifier of a lower Focus Phrase. As for their licensing, we preliminarily adopted Belletti's (2001) suggestion that a focus feature may license DPs; how this licensing is possible is an issue we wish to address in a near future.

\section{REFERENCES}

BAILYN, J. A configurational approach to Russian "free" word order. Doctoral dissertation - Cornell University, 1995.

BELLETTI, A. The Case of unaccusatives. Linguistic Inquiry, Cambridge, v. 19, p. 1-14, 1988.

BELLETTI, A. "Inversion" as focalization and related questions. Catalan Working Papers in Linguistics, Barcelona, v. 7, p. 9-45, 1999.

BOŠKOVIĆ, Z. On the locality and motivation of Move and Agree: an even more minimal theory. Linguistic Inquiry, Cambridge, v. 38, p. 589-644, 2007.

CARDINALETTI, A. A second thought on emarginazione: destressing vs. 'Right Dislocation'. In: CINQUE, G.; SALVI, G. P. (Ed.). Current Studies in Italian Syntax: essays offered to Lorenzo Renzi. Amsterdam: North Holland, 2001. p 117-135.

CHOMSKY, N. The minimalist program. Cambridge: The MIT Press, 1995. 420 p.

CHOMSKY, N. Minimalist Inquiries: The Framework. In: MARTIN, R.; MICHAELS, D.; URIAGEREKA, J. (Ed.). Step by Step. Cambridge: MIT Press, 2000. p. 89-155.

HORNSTEIN, N. A theory of syntax: minimal operations and universal grammar. Cambridge: Cambridge University Press, 2009. 204 p.

MIOTO, C. Focalização e quantificação. Revista Letras, Curitiba, n. 61, p. 169-189, 2003. 
NARO, A. J.; SCHERRE, M. M. P. Origens do Português Brasileiro. São Paulo: Parábola Editorial, 2007. 208 p.

NUNES, J. Relativized minimality and the Extended Peeking Principle. Cadernos de Linguística, v. XIV, p. 73-86, 2007.

REINHART, T. Interface strategies: optimal and costly computations. Cambridge: The MIT Press, 2006. 340 p.

SIBALDO, M. A. Nominais pós-verbais em estruturas inacusativas: o efeito de definitude no Português Brasileiro. Manuscrito nãopublicado.

STJEPANOVIC, S. A Word-order paradox resolved by copy deletion at PF. Linguistic Variation Yearbook, v. 3, p. 139-177, 2003.

ZUBIZARRETA, M. L. Prosody, focus, and word order. Cambridge: The MIT Press, 1998. 213 p.

\section{ABOUT THE AUTHOR}

Leonor Simioni is is currently a $\mathrm{PhD}$ student in Linguistics at Universidade de São Paulo. Her main research interests are clausal and DP-internal agreement phenomena and the syntax and semantics of DPs. She is a member of the project "Sintaxe Gerativa do Português Brasileiro na Entrada do Século XXI: Minimalismo e Interfaces", coordinated by Jairo Nunes and funded by FAPESP.

E-mail: leonor.simioni@usp.br. 